$$
\begin{aligned}
& \text { SF } 285 \\
& \text { S } 855
\end{aligned}
$$





\section{THIRTY YEARS}

WITH

THE HORSE.

\section{BY \\ SAMUEL P. STICKNEY,}

Equestrian and Circus Proprietor.

CONTAINING DIRECTIONS FOR THE BREAKING, TRAINING, KEEPING AND GENERAL TREATMENT OF THAT NOBLE ANIMAL; BEING THE RESULTS OF OVER THIRTY YEARS' EXPERIENCE.

A $480, A$

\section{BIOGRAPHICAL SKETCH}

OF

\section{SAMUEL P. STICKNEY,}

BY A MEMBER OF THE NEW YORK PRESS.

PRICE, TWENTY-FIVE CENTS.

5 New Work:

PUBLISHED BY MURRAY \& 0 . 


$$
\begin{aligned}
& S F 285 \\
& S 855
\end{aligned}
$$




\section{BIOGRAPHY OF SAMUEL P. STICKNEY.}

WHEN we read the opinions of any acknowledged authority, in this or that art or science in which we feel interested, we naturally wish to know something of the personal history and character of the man himself. We feel an interest in him, arising from our admiration of the skill and experience which have made him distinguished; and also because, by knowing him, we can the better tell what value to set upon his judgment.

For these reasons it has been deemed fit that a biography should accompany this pamphlet, which sets forth so many directions, and principles of importance, to all who own horses or have anything to do with them; direetions and principles which have irresistible weight, because sanctioned by him,-a man whose name as an equestrian and horse-owner has as wide a celebrity as that of any man living; a fame, too, which is not of mushroom growth, but the legitimate offspring of more than thirty years of active equestrian life.

As this work is to go before the world, and will doubtless exercise great influence over the minds of thousands, who either ride, drive, own or have the charge of horses, it is due to the subject of this biography to state that it is written, not to give force to his opinions in the minds of veteran horse-owners and dealers in this country, for they have long known Mr. Stickney better than pen or type can portray him.

This prefatory sketch is chiefly published for the information of the masses, who have but an imperfect knowledge of him. It will also serve as an interesting memorandum, for his old personal friends, throughout the United States; and for future reference by all who cherish and regard the manly equestrian profession, its genial members, and the noble animal which is its expressive emblem.

Samuel P. Stickney was horn in Boston, Mass., on the 12th of Feburay, 1810. He is the fourth son of Benjamin B. Stickney, a highly esteemed resident of Billerica, of the same State. 
In his earliest years, his father having removed to Boston, Samuel evinced a remarkable fondness for horses; and though he showed as much aptitude for learning as any intelligent boy of his age usually does, and held his own, as a scholar, with any of his schoolmates, under the somewhat severe discipline of the late Charles Emerson-a brother, by the way, of Ralph Waldo Emerson-still he loved horses; and we may suppose him to have plead with his parents his desire to quit his studies, in this wise:- "Not that I love Emerson less, but that I love horses more!" While at Emerson's school-the "Fort Hill School "-he was a classmate of the lamented young American tragedian, Charles Henry Eaton, who died in Pittsburgh, Pa., June 4th, 1843, from a fall at the Exchange Hotel.

The passion of this youth for horses and for equestrian distinction prevailed with his parents; and we find that he made his first appearance, as a rider in the Circus, in Washington Garden, Boston, opposite the Common, in 1822. The veteran James West was then there, manager and proprietor, with an English troupe of artists, among whom our American boy-rider showed to brilliant advantage, before crowds of the genial, good old-fashioned families of that day.

In the year of $1825-6$, his skill, grace and daring as a rider and general performer having enabled him to command "good terms" from managers, he made his first appearance in Now York; performing at the Lafayette Circus, in Laurens street, between Canal and Grand. This establishment was then under the management of John Miller; and subsequently of Charles W. Sandford, Esq., then a member of the New York Bar. The latter gentleman afterwards distinguished himself as a lawyer and politician and in military life ; in the last profession holding the present rank of Major General.

Having won early and marked distinction by his prowess as an artist, and having acquired the attachment of his acquaintances in private by his amiability of nature, as well as their implicit confidence by his unswerving integrity, in 1826 he was offered a partnership by Mr. Fogg, and accepted it, becoming his associate at Military Garden, Brooklyn, L. I. 
Thenceforth his progress, in fame, ability and fortune, was upward and onward. No member of the profession was more noted for strict and continual attention to business. It absorbed nearly all his time and thoughts; and it was the case with him as it has been with nearly all who have excelled in his art, that his labors toward perfection were much greater in his practicing in the ring by day, than in his performances by night. The real work was at rehearsing his exploits; the gay and festive audiences little reflecting that what was done with such seeming ease, before their wondering eyes, was the fruit of countless, painful, persevering, hazardous trials, when no admiring eye was present to witness, and no applausive hand to cheer.

This devotion to his romantic calling could not but result in the most intimate knowledge of the nature, habits and proper treatment of the horse, under all circumstances and in all moods. From his youth, we might almost say from his cradle, the horse has been his constant companion, up to the present time; and not only his companion, but his friend; for Mr. Stickney was one of the earliest who recognized the fact that kindness, patience and perseverance are the chief means of controlling the horse; not rudeness, force, nor cruelty. Hence the horse is his willing scholar and his friend; and the same may be said of Rarey, a late, but enlightened authority in these matters.

As a proof of the long established reputation of Mr. Stickney in the equestrian art, it is only necessary to mention the fact, that, in the course of the last thirty-six years, he has been, not only a renowned equestrian and athlete, but a manager and proprietor of circuses, in the following cities and towns in the United States, independent of the innumerable other places which are included in the grand routes of circuses, during their "traveling seasons," in the United States, Cuba, the Canadas and the British Provinces :-Boston, New York, Richmond, Raleigh, (N. C.) Columbia, (S. C.) Augusta, (Ga.) Charleston, (S. C.) Mobile, (Ala.) New Orleans, Natchez, (Miss.) Memphis, (Tenn.) St. Louis, Louisville, Cincinnati, Pittsburgh, Philadelphia, Washington, (D. C.) and New York ; in which last named city, having returned to it after an absence of thirty-two years, he concluded, 
in the autumn of 1861 , to attempt the hazardous task of reviving the fallen fortunes of the Old Bowery Theatre ; once glorious under the auspices of Thomas Hamblin, but of late years the sad victim of numerous mismanagements, known and unknown.

With his accustomed energy, and having the influence of unimpeachable character to inspire confidence, in November, 1861, he opened the old shrine, with a very large and talented double company, - equestrian and dramatic,- and aided by the veteran dramatic author and stage manager, John Foster, he conducted the theatre through a highly successful season of nineteen weeks, giving employment to an immense number of people, in the midst of the most unfavorable war-times; and securing large audiences, while many deserving rival houses were doing next to nothing. This fact is significant and needs no comment.

As a general performer, Mr. Stickney has been noted for versatility, riding all known acts of classic or scenic horsemanship, from one horse up to eight, and excelling, in his day, as a vaulter, tumbler, etc. Among his well known contemporaries in the profession were John Gossin, Christopher Hughes, William Lawson, John Rogers, Isaac Asten, John Shey, William Hunt, George Sweet, John Andrews, and others, famed and accomplished in their day and generation, but now, alas! removed from the scenes of their ancient triumphs and the circles of their friends.

Mr. Stickney was married in Philadelphia, in the year 1831, to Miss Christiana Wolfe, a native of that city. She was an attractive and most exemplary lady. By her truly feminine, womanly traits she inspired the enduring esteem and attachment of unnumbered friends. Her sympathies were ever alive for the wronged or unfortunate. She was an ornament to her sex. She was a good wife and a good mother, fond and devoted in each of those sacred relations, and her unpretentious character made her virtues shine the more. In 1861, while traveling in Connecticut with her husband and daughter, Sallie Elouise, she was attacked by a malignant disease which resulted fatally, and she was buried in Bridgeport in that State. 
The issue of the marriage were six children - Rosaline, Charles, Samuel E., Sallie Elouise, Robert Theodore and Emma.

Of this, Rosaline, the eldest, was the first female equestrian who ever performed in America with marked distinction. She was married, in 1850, to Monsieur Benoit, brother to the eminent French equestrienne, Madame Tournaire, and himself a gifted horseman. There were three children by this marriage, two of whom are still living. The mother died in Philadelphia, in 1854.-Samuel E. Stickney is the popular clown and general performer.-Sallie Elouise, named after the whilom "Belle of Kentucky," Sallie Ward, has been distinguished as a star rider almost from infancy. In 1862 she married another eminent member of the profession, Mr. Samuel Omar Kingsley, who for so long a time astonished the public, in his unparalleled disguise as a woman, under the celebrated alias of "Zoyara."-Robert Theodore, the youngest brother, is everywhere known as the champion boy-rider of America.-Last and youngest of all, and as promising as any, is "Little Emma," the graceful and spirituelle danseuse and juvenile equestrian.

An interesting item in this connection may not be unacceptable to those who peruse this work. We copy it as it appeared in the columns of that able weekly journal, the New York Sunday Atlas, edited by Messrs. Anson Herrick and Henry Morford :-

\section{POETICAL ADDRESS,}

On the occasion of the Complimentary Benefit to Manager SAsruku P. STICKNeY, at the Bowery Theatre, Saturday evening, March 8th, 1862, after thirty-two years' absence from New York. Spoken by Charles Foster, Tragedian.

By William O. Eaton.

Before, with cordial hearts, and faces bright,

We hail the veteran horseman of to-night,

We can a transient thought to him assign

Who was a favorite here in auld lang syne!

In the first Chatham's ring; hard by this spot,

The temple vanished and almost forgot, 
He graced the lists, in earliest manhood's pride,

And New York thronged to see the champion ride. Three times ten years and more are gone since then, And he returns to stride the steeds again, To urge their fleetness, try his art once more, And re-enact the cavalier of yore.

'Tis well to see so full a gathering here, To crown the evening of his long career, Who, like some old crusader, from afar, Turns his proud horse toward the Northern star, And, all the turmoils of his campaigns past, Reins in his gallant steed at home at last, Where early friendships for his coming wait, And welcome stands to greet him at the gate. Trust me that when he comes before your gaze, He'll miss full many a friend of other days ; And though ambition nerve and kindness cheer, Old recollections will demand a tear. In this long thirty-two years' flight of time, His life has shifted on, from clime to clime;North, South, East, West, all sections of the land Have known his managerial command, Whose various fortunes, all confirming fame, Have never left a shadow on his name! To-night, the artist, manager and man Once more appears. Deny his claims who can ? Ye young New Yorkers! when he mounts his horse, The praise your fathers gave him "endorse; With yours the absence of their hands supply, And light the old-time ardor in his eye;

Show you're not blind to merit and renown, Although not cradled in your native town; Refute the maxim, untrue as unkind, That "Out of sight is also out of mind;" And feel that honor on yourselves you bring, To welcome back the Veteran of the Ring!

Of such a man, such an established and universally acknowledged authority, we have only to add-Mark his advice! 


\section{THE HORSE.}

Rules adopted by Samued P. Stickney, for his Breaking, Training, Keeping, and general Treatment.

\section{FIRST PRINCIPLES.}

The three leading rules are: Be always patient, Be always kind, Be always persevering with the horse. To these indispensables may be added the following principles, in which Mr. Stickney has an abiding faith.

Any horse may be taught to do anything that a horse can do, if taught in a systematic and proper manner.

A horse is not conscious of his own strength, until he has resisted and conquered a man ; and even in cases where he has temporarily triumphed he may yet be subdued. By taking advantage of man's reasoning powers a horse can be handled in such a manner that he shall not find out his strength.

By enabling a horse to examine every object with which we desire to make him familiar, with the organs naturally used for that purpose, viz., seeing, smelling and feeling, you may place or display the object around, over, and on him, provided that it does not hurt him or make him feel disagreeable.

The colt should be accustomed to kindness, and gentle, yet firm handling, from the first, and in this manner learn perfect obedience to his master's will. The halter should be placed upon him when quite young, and he should learn to be guided by it in any direction, and with ease ; and as he grows up, one lesson after another may be added, as the onner's wishes or fancy may dictate, so that, when the time comes that his services are demanded, he is ready trained for the service, educated in the way he should go, and he will walk therein. The whole process should be one of careful aroidance of influences tending to 
create bad habits, teaching the animal what it will be required to know, before that requisition comes, and by education supercede the necessity for the unphilosophical, and often brutal "breaking."

\section{TAMING A VICIOUS HORSE.}

The following instance may serve as a guide for taming all obstinate or vicious horses. It shows the superiority of "moral suasion" over cruel, brute force. A gentleman having bought an apparently untameable but splendid horse and declared his resolve to "conquer or die," led him from his stable in the presence of an excited crowd, put a saddle on him, buckled it with uncommon tightness, and after trying the stirrups, to see that all was sound and right, with a single bound was in his saddle.

Now commenced a scene of rearing, and springing, and pitching unlike anything ever before witnessed. In retaliation, the rider commenced using the cow-hide freely over the rump, about the sides and legs of the animal, and at length over his head, eyes, ears and mouth. It was evidently a battle between two equally determined, but unequally powerful opponents-a trial of animal strength—an exhibition of dexterity-on the part of the animal, to throw off the disagreeable load; on the part of the disagreeable load-the man-to conquer, to subdue, to maintain his position. But the horse, being the stouter of the two, was the victor, and would have thrown his load a rod at least from his back, but for the rider's foot having caught in the stirrup ; and in that plight, the horse would soon have kicked his brains out, if he had any, but for the interference and assistance of the by-standers, who soon liberated the prisoner from his critical position.

Another gentleman present, determining to try Stickney's plan, now bought the animal for a nominal sum, took him home, put him in a clean, light, nice stable, fed him well, brushed, combed, conversed with and caressed him, in person, and having spent several days in thus obtaining a pleasant introduction to him, at last placed a saddle gently on his back. And annexed is what the gentleman said himself:- 
"I crawled shyly upon his back, setting down so easily that he could scarcely distinguish the time when I was fairly fixed; my head mean time, and for some time afterward, close to his. I made no motion for him to go, but slipped off, and went for a pair of mittens, though it was July; put on the mittens and again mounted his back cautiously-no, not cautiously, for it will never do to be cautious - but in a friendly, familiar manner, as much as to say, I have a right to a place on your back, but, then, it is with your leave, sir. After turning him around once by the bridle, I was again off to get my hat, then my whip, etc., etc., and finally took off his saddle and put him back into his stall. This I did several times, perhaps more times than was necessary, but I was in no hurry.

"I next took him into the yard, and, jumping upon another horse, rode several times around him, then left that and mounted him, and rode several times around the first horse. This was a great feat-it was 'glory enough for one day;' I therefore put the horse up and left him for a day.

"The next day I tried both horses again, but rode a longer time than the first day. Again, I ventured still farther, riding around my house, then down the road to the brook and back, until finally, I can take a journey on the best saddle horse I ever owned, which cost me but fifty dollars."

Now whe will say that horses have not sense? Who will say that they must not be treated, at least as we would treat a dog, or a cat, or a bird, that we would wish to tame and instruct?

\section{TEACHING A HORSE TO PERFORMI TRICKS.}

Select a good-shaped, bright-eyed, nimble and playful horse, not too large, nor too stoutly built; for some horses, says Mr. Stickney, are made only to work, and others to be lazy. Then carefully observe the following directions, the result of many years' experience in training horses for the Circus :-

Treat him with patient kindness. If you crack your whip around his legs occasionally to urge obedience, do not do it angrily or cruelly, so that he may think you unreasonable, unfriendly or ill-tempered. 
Take the whole care of him in the stable yourself. $\mathrm{He}$ should be made to think you his best friend, and that all he does is done for you.

Never allow any other person or animal to be present when you are instructing him.

Undertake but one trick at a time.

When he performs well always caress, fondle and feed and praise him. Put your arm around his neck, and talk much to him in kind tones. He understands tones and looks and manners, if not words. And now, observing the above rules, you may begin by taking a handkerchief and placing it in a certain part of the stable. Then, pointing to the handkerchief, say, "Bring me that handkerchief, sir," leading the horse to it (first presuming, however, that he has seen and smelt of it twenty times before), bearing his head toward it, and at the same time lifting it up to his mouth. Put it into his mouth-if he is disposed to drop it, hold it to his mouth, and lead him to the other side of the stable and put it down. Now take the handkerchief and carry it back to where you put it first, then come back to the hcrse and say, as before, (in fact, always use the same expression and in the same tone of voice) bring me that handkerchief, sir; if he does not start for it, lead him as before, and pass through the whole ceremony precisely as the first time. The third or fourth time, you can venture to snap your whip and manifest some signs of displeasure, but finish with a friendly gesture and word, and again lead him to the ohject, and go through the whole round of ceremony. He will at length go so far as to go and take the handkerchief in his mouth, and then from pure mischief, perhaps, shake it about, or carry it anywhere else but where you want him to. Then snap your whip, and again make him carry it to the place where you were standing or sitting, Follow this up and you will soon learn your horse to bring your handkerchief to you without your moving from your position; then your hat, gloves, or any other object.

If it is a pail, and he takes hold of it by its side instead of the handle, go to him, take it from his mouth, and put the handle 
in his motth, saying, "That is not right, sir, this is the way!" Some such expression as this should be always used, and always in precisely the same way, when he does not perform correctly, and he will soon learn what is meant by it, if applied to any other transaction improperly performed.

You may now go on and teach him what you please. It is by such means that a Circus horse is taught innumerable feats.

\section{BREAKING A COLT.}

As you draw near the horse, or colt, if he turns from you, stop until he stops and has taken another look at you. He will then allow you to approach still nearer. If he again starts, stop yourself again. It is of no use to follow him while he is in motion. He can move faster than you can, and will only widen the distance between you.

When you have succeeded in reaching his head, pat him on the neck, put your head close to his, and talk to him, and he will soon be pleased with the familiarity. If you are not in too great haste, it is better to do this with him frequently, before approaching him with anything in your hand.

So much being accomplished, you can now approach him with a halter, whip, or any thing else; but if he turns from you, do not follow him up.

After you have fondled with him several times with a whip, halter, harness or anything else you please, take a leather halter (in no case use a rope halter) and put it to his nose, then rub it on his neck, around his head, mouth and nose, being careful always not to approach too near his eyes. Do this frequently before putting it over his head. When you get ready, put it over his head so easily and with so much unconcern that he will not know you have any design in doing it. Do not attempt now to fasten it, nuless he is very tame, and submissive. Take another opportunity.

After your colt has become used to the feeling of the halter, you can then lead him about; but if he falls back, go up to him and pat him on the neck. Do n't let him have a chance to try his strength; if you do, he will find out that he is stronger than you are, which he should never know. 
Every colt should be made familiar with drums, fifes, horns, railroad cars; and with various colors and objects. But never approach them or look at them while making any uncommon noise for the purpose of breaking them. Whatever you do in this line, should be done, at first, at a distance, until the colt cares nothing about it; then approach a step nearer. Aroid all sudden frights.

It is better to pasture them, if possible, near but not too near a railroad track, and then in a lot adjoining a track. If you cannot do this, the first opportunity you can have, take them near, but again not too near, a railroad track. Next time a little nearer, always letting them see the cars as they pass.

\section{TO PREVENT TIIE IIABIT OF KICKING.}

Kicking against the sides of the stall can generally be prevented, by attaching thorns to the sides of the stall, or anything that will prickle without injuring the feet. Kicking in the harness is best conquered by stout straps, so adjusted as to prevent his raising his hind feet. The strap must be very strong and a little springy, and then it must be resorted to more for the purpose of preventing the horse from breaking the carriage, than with any expectation of reforming him.

TO CATCII COLTS IN PASTURES.

If they are very wild or shy, two or even three should be employed to go on all sides and gradually approach them. Do not look directly at them, nor approach in a direct line, nor raise the hands as if to head them off. You must not let them mistrust that you want to catch them. Let one who is on a horse approach slowly, and if your horse will nibble the grass, let him do so for a minute, and then take a step nearer; by such means you can soon go in among them, and after your horse has smelt of them and they of him, then turn toward your home, and in most cases they will follow into the barn yard. If they will not do it at first, perseverance will always succeed. It is sometimes well, but not always necessary, to feed them. 
Avoid all haste, noise, flurry, excitement. If you get out of patience, do not let your colts know it; if you do, you will have lost all your labor thus far. If you cannot control yourself in this matter, it is doubtful whether you can control the colts after you catch them. Another mode is to go to the pasture and walk around the whole herd quietly, and at such a distance as not to cause them to scare and run. Then approach them very slowly, and if they stick up their heads and seem to be frightened, hold on till they become quiet, so as not to make them run before you are close enough to drive them in the direction you want them to go. And when you begin to drive, do not flourish your arms or halloo, but gently follow them off, leaving the direction free for them that you wish them to take.

\section{RESTLESSNESS WIILE BEING SHOD.}

If a young horse is unwilling to be shod, he should be allowed to see other horses go through the operation before taking his turn. Then take up his foot frequently and hold it as the smith does, till he cares nothing about it. Then hammer it, and do whatever else will be an imitation of the process of shoeing. II will thus soon be prepared for the real act of shoeing.

\section{HOW TO TREAT A STUBBORN COLT.}

If the animal you are operating upon seems to be of a stubborn or mulish disposition rather than wild; if he lay back his ears as you approach him, or turns his heel to kick you, he has not that regard or fear of man that he should have, to enable you to handle him quickly and easily; and it might do well to give him a few sharp cuts with the whip, about the legs, pretty close to the body. It will crack keen as it plies about the legs, and the crack of the whip will affect him as much as the stroke; besides, one sharp cut about the legs will affect him more than two or three over the back, the skin on the imer part of his legs, or about his flanks, being thinner and more tender than on his back. Only whip him enough to scare him. We do n't wish to hurt, but to scare the bad disposition out of him. Whatever you do, 
do quickly, sharply, vigorously, but without show of anger. Scaring must be done at once. Never have a pitched battle with your horse, nor whip him till he is mad and will fight you. You would thus lose his confidence in you.

\section{TO PREVENT ROLLING IN TIIE STALL.}

Build a narrow platform, eighteen to twenty-four inches in width, slanting at an angle of thirty to forty degrees, so that it will form a pillow for his head and neck; then adjust a rope so that as he lies down his head will naturally rest on the platform, or pillow. He will not roll, unless he can get his head as low as the floor of the stable.

\section{REMEDIES FOR BALKING HORSES.}

In the first place never teach your horse to balk, by giving him a greater load than he can carry, or requiring him to go up too steep a hill without permitting him to stop. If you tell him to stop, in going up a steep hill, it is better than to allow him to do it of his own accord. This will teach him that he is to stop only at your will, and that you are not unreasonable in your de. mands. I believe that all balky horses are in the first instance taught to balk by their careless and inconsiderate owners, who overload them, and allow them to stop or go, according to their own will.

But what shall we do with a horse who has thoroughly learned to balk, and whom whipping only hardens? Desperate remedies should sometimes be used for desperate cases, and you may in such a case either kill your horse as not being worthy the oats you give him, or you may fasten him to a strong carriage, put on a strong harness and reins, and, seating yourself firmly in the vehicle, drive on; if he balks, set fire to a bunch of shavings or a newspaper at his heels, or a bunch of fire-crackers; he is bound to go in such a case-perhaps too fast for you-but of this you must run your risk. It is a desperate remedy, but when kindness and good treatment do not succeed, such a remedy will succeed better, and is more humane, than beating, unmerciful whipping, etc., which seldom succeed at all. 
Caress him kindly is the general rule, and if he don't understand at once what you want him to do, he will not be so much excited as to jump and break things, and do everything wrong through fear.

In regard to a balking team of horses, it should be obserred that almost any team, when first balked, will start kindly if you let them stand five or ten minutes, as though there was nothing wrong, and then speak to them with a steady roice, and turn them a little to the right or left, so as to get them both in motion before they feel the pinch or the load. But if you want to start along a team that you are not driving yourself, that has been balked, fooled, and whipped for some time, go to them and hang the lines on their hames, or fasten them to the wagon, so that they will be perfectly loose; make the driver and spectators, if there are any, stand off some distance to one side, so as not to attract the attention of the horses; unloose their check reins, so that they can get their heads down, if they choose; let them stand a few minutes in this condition, until you can see that they are a little composed. While they are standing you should be about their heads gentling them; it will make them a little more kind, and the spectators will think you are doing something that they do not understand, and will not learn the secret. When you have them ready to start, stand before them, and as you seldom have but one balky horse in a team, get as near in front of him as you can, and if he is too fast for the other horse, let his nose come against your breast; this will keep him steady, for he will go slow rather than run on you; turn them gently to the right, with the wagon; have it stand in a favorable position for starting out, letting them pull on the traces as far as the tongue will let them go; stop them with a kind word, gentle them a little, and turn them back to the left, by the same process. You will have them under your control by this time, and as you turn them again to the right, steady them in the collar, and you can take them where you please.

\section{UNWILLTNGNESS TO BF MOUNTED}

Generally proceeds either from playfulness - in which caso you 
must give him more hay and less oats_or momentary restive. ness or unwillingness to be driven; in which latter case give him more oats and less hay. Wait awhile, use kind words, and occasionally a crack of the whip-but do not whip him. Kindness will cure that habit.

\section{CRIT-BITING.}

The only certain cure for this is an iron muzzle, with bars just wide enough to allow him to pick up his grain and draw in his hay with his tongue, but not to get hold of anything with his teeth.

\section{RUNNING AWAY.}

The best way to cure this, if it is a settled habit, is to get your horse on a good road, and if he starts, let him go, and the moment he slacks, give him a sharp cut with the whip, until he has had as much running as he wants.

\section{BITING AT YOU.}

Mr. Stickney says he has seen horses whipped till nearly dead, but to no effect. If you can obtain something exceedingly disagreeable to the taste of a horse, as some very bitter herb, saturate a piece of cloth, and wind it around a stick for him to bite at; it will often, in connection with kind treatment, have a tendency to break him. A single sharp cut of the whip across the mouth on the instant, will sometimes do good ; but unmerciful whipping, raving, swearing-never!

\section{RESTIVE HORSES.}

To subdue the dangerous habit of restiveness, mildness is the only method. Whipping, shouting, jerking, any harshness make the animal worse. Either kindness cures him, or he is in. curable.

TO INDUCE HIM TO LIE DOWN AT NIGIT.

Horses that never lie down when they sleep, will not do as well as those who are in the habit of it. They perhaps are afraid of being caught by the halter, or they have already been 
cast in the night, and do not like to try it again. Such horses should be let loose in a stable at night, or in a large stall, without being tied, and furnished with a tempting bed, until the habit of lying down is acquired, and the fear of it removed.

\section{TO MAKE HM LIE DOWN AT ANY TIME.}

Bend his left fore-leg and slip a loop over it, so that he cannot get it down. Then put a surcingle around his body, and fasten one end of a long strap around the other fore-leg, just above the hoof. Then place the other end under the before-described surcingle, so as to keep the strap in the right direction; take a short hold of it with your right hand; stand on the left side of the horse; grasp the bit in your left hand, pull steadily on the strap with your right; bear against his shoulder till you cause him to move. As soon as he lifts his weight, your pulling will raise the other foot, and he will have to come on his knees. Keep the strap tight in your hand, so that he cannot straighten his leg if he rises up. Hold him in this position, and turn his head towards you; bear against his side with your shoulder, not hard, but with a steady, equal pressure, and in about ten minutes he will lie down. As soon as he lies down, he will be completely conquered, and you can handle him as you please. Take off the straps, and straighten out his legs; rub him lightly about the face and neck with your hand the way the hair lies; handle all his legs, and after he has lain ten or twenty minutes, let him get up again. After resting him a short time, make him lie down as before. Repeat the operation three or four times, which will be sufficient for one lesson. Give him two lessons a day, and when you have given him furr lessons, he will lie down by taking hold of one foot. As soon as he is well broken to lie down in this way, tap him on the opposite leg with a stick when you take hold of his foot, and in a few days he will lie down from the mere motion of the stick.

\section{BIINDS OR BLINKERS.}

Mr. Stickney declares that all his experience with, and olservation of, horses convince him that blinkers should never be 
used; and that the sight of the horse, for many reasons, should not be interfered with, in any way. Howerer wild or nerrous a horse may be, he can be taught, in a very short time, to understand any olject and not to fear it, however frightful at first sight. Horses can be broken hetter and in less time, without blinkers; but horses that have always worn them will notice the sudden change, and must be treated carefully the first drive. After that they will drive better without than with. Blinkers are rapidly going out of use in the United States. The horse, when permitted to see fully, uses his eyes with great judgment. Like Rarey and Youatt, Mr. Stickney considers the horse a thinking animal-much more so, indeed, than many men give signs of being.

\section{RULES FOR BREEDING HORSES.}

The breeding mare needs consiant care. She must be kept in good health and condition-must be fed with care, both as regards quantity and quality; - -must be sheltered from storms and bad weather; -must have exercise and room for recreation, aroiding sudden, violent exertion; - must be liept free fiom the noxious gases of foul and ill-rentilated stables; - should be combed and rubbed frequently, and, in short, everything should be done which teads to cullivate and sustain that condition of life, strength, action, and spirit, to be desired in the offspring. The forming animal derives no elements of its being from other source than the mother's system. During gestation, her vital fluid fills the fotal veins, and if, from any depressing or exhausting influence, that blood is deficient in vitality, it cannot supply that life and energy, that perfection of development, to the new being which a better condition would impart. Every influence affecting injurionsly the mother's liealth, vitiates the life fountain of the new being; hence the necessity and value of the utmost care and attention during the period of gestation.

All the attention requisite before foaling, is equally important afterwards. In the one case, the foctus derives its nourishment direct from the blood of the mother; in the next, the foal obtains its sustenance from the milk made from that blood, and it is not 
less important that the blood be healthy and pure to insure the proper quantity and quality of nutriment to the young animal. For this reason the mare should not be put to hard work soon after foaling, nor, indeed, to severe and constant toil during the time of suckling her young. She should be well fed, and allowed good pasturage, affording both food and room for exercise. An idea that half-starved and stunted colts make tough, hardy horses, has long existed among a portion of the farming community; and so opposed is it to all facts, so contrary to all the teachings of reason and philosophy, so absurd in itself, that its very existence is astonishing. As to the growing colt-with liberal range, he should have good shelter from storms and the inclemencies of the weather. Too often, however, after weaning, he is left to struggle on as he can, and, becoming poor and dispirited, may be seen shivering beside a fence, rheum running from his eyes, his rough, shaggy, dirty coat a habitation for vermin, and himself a sad specimen of poverty and misery.

\section{TIIE KIND OF STABIE FOR HIORSES.}

Everything possible should be done to prevent the stable from being either hot or stifled. It should be kept airy, cool and wholesome. The rentilation should be perfect, especially in summer. Plaster of Paris should be used freely about the stable, to absorb the noxious gases. There should also be plenty of light, and the floor should not be steep. Steep stable-floors often cause sprung knees. Make the horse's home clean and comfortable. And in regard to light, it seems to be a matter of no doubt that horses kept in dark stables are frequently notorious starters, and that abominable habit has been properly traced to this cause.

Give a horse a manger to feed out of, so that he can enjoy eating, and do not oblige him to steal his fodder from a rack, with narrow spaces, as though he did not deserve his keeping. It is thought that a horse will waste his hay if he is fed from a manger; but he will not, if he has good hay, given in proper quantities.

FAITHFUL AND JUDICIOUS GROOMING.

Many persons go at this business as if they were rubbing the 
skin of the rhinoceros, instcad of that of one of the most sensitive of the animal race. A comb with part of the teeth gone should never be used; and whatever be the condition of the comb, it should be handler' earefully about the legs and head of the animal. If a horse is not thus handled, he will soon become restive, and perhaps acquire the pernicious habit of kicking, or biting.

The stabled horse, highly fed, and irregularly worked, is here spoken of. It would be wall for the proprietor if he were to in. sist-and to see that his or lers are really obeyed-that the fine coat in which he and his groom so much delight, is produced by honest rubbing, and not by a heated stable and thick clothing, and most of all, not by stimulating or injurious spices.

As to the farmer's horse, regular grooming, by rendering his skin more sensible to the alteration of temperature, and the inclemency of the weather, would be prejulicial. The horse that is altogether turned out, needs no grooming. The dandruff, or scurf, which accumulates at the roots of the hair, is a provision of nature to defend him from the wind and the cold.

\section{DAILY EXERCISE.}

Every horse should have daily exercise. A gentleman's or tradesman's horse should have at least two hours' exercise every day, in order to be kept free from disease Such horses suffer a great deal more from isleness than from work.

\section{LITTTER.}

No heap of litter should be suffered to remain during the day in any part of the stable. All fermenting dung should be removed, and gutters should be contrived for the speedy draining off of urine.

\section{KINDS AND RUALITIES OF FOOD.}

There are few horses that do not halbitually waste a portion of their hay; and by some the greater part is pulled down and trampled under foot, in order first to cull the sweetest and best locks, and which could not be dono while the hay was enclosed 
in the rack. The observation of this induced the adoption of manger-feeding, or of mixing a portion of chaff (i. e., cut feed) with the grain and beans. By this means the animal is conpelled to chew his food; he cannot, to any degree, waste the straw or hay; the chaff is too hard and too sharp to be swallowed without sufficient mastication, and, while he is forced to grind that down, the oats and beans are ground with it, and yield more nourishment ; the stomach is more slowly filled, and therefore acts better on its contents, and is not so likely to be overloaded; and the increased quantity of saliva thrown out in the lengthened maceration of the food, softens it, and makes it more fit for digestion.

Chaff may be composed of equal quantities of clover or meadow hay, and wheaten, oaten or barley straw, cut into pieces of a quarter or half an inch in length, and mingled well together; the allowance of oats or beans is afterwards added, and mixed with the chaff:

For the agricultural and cart-horse, eight pounds of oats and two of beans should be added to every twenty pounds of chaff. Thirty-four or thirty-six pounds of the mixture will be sufficient for any moderate sized horse, with fair, or eren hard work. The dray and wagon horse may require forty pounds. Hay in the rack at night is, in this case, supposed to be omitted. The rack, however, may remain, as occasionally useful for the sick horse, or to contain tares or other green feed. We would caution the farmer not to set apart too much damaged hay for the manufacture of the chaff. Much more injury is done by eating damaged hay or musty oats than is generally imagined. There will be sufficient saving in the diminished cost of the provender by the introduction of the straw, and the improved condition of the horse, without poisoning him with the refuse of the farm. For old horses, and for those with defective teeth, chaff is peculiarly useful, and for them the grain should be broken down as well as the fodder.

The farmer should see that the pasturage is thick and good. Few grooms make good Grues. A pound of meal in a gallon of water should be constantly stirred till it boils, and five minutes afterwards. 
BARLEX is more nutritious than oats. When barley is given, the quantity should not exceed a peck daily. It should always be bruised, and the chaff should consist of equal quantities of hay and barley-straw, and not cut too short.

A horse that is fed on whest should have very little hay. 'The proportion should not be more than one truss of hay to two of straw.

$\mathrm{B}_{\mathrm{RAN}}$, or the ground husk of the wheat, used to be frequently given to benefit some sick horses on account of the supposed advantage derived from its relaxing the bowels.

All travelers who allow BEANs to their horses on a journey, find their spirit and condition much better from this mixture with their food.

Peas are a little more nourishing than beans, and not so heating.

Lixseed, raw, ground, or boiled, is useful to horses in cases of catarrh.

Carrots are the best root given to horses; a good substitute for grass, and an excellent alterative.

Potatoes, raw and sliced with chaff, are very good. When boiled or steamed, they are still better.

HAY is most in perfection when it is ahout a twelve-inonth old. The horse would prefer it earlier, but it is neither so wholesome nor so nutritive, and often has a purgative quality. When it is about a year old, it retains or should retain somewhat of its green color, its agrecable smell and its pleasant taste. It has undergone the slow process of fermentation, by which the sugar which it contains is developed, and its nutritive quality is fully exercised. Old hay hecomes dry and tasteless, and innutritive and unwholesome.

It is a good practice to sprinkle the hay with water in which salt has been dissolved. It is evidently more palatable to the animal, who will leave the best unsalted hay for that of an inferior quality that has been moistened with brine; and there can be no doubt that the salt very materially assists the progress of digestion. The preferable way of salting hay is to sprinkle it over the different layers as the rick is formed. 
Of the value of TAREs, as forming a portion of the late spring and summer food of the stabled and agricultural horse, there can be no doubt. They are cut after the pods are formed, but a considerable time before the seeds are ripe. They supply a larger quantity of food for a limited time than almost any other foragecrop. When surfeit-lumps appear on the skin, and the horse begins to rub himself against the divisions of the stall, and the legs swell, and the heels threaten to crack, a few tares, cut up with the chaff, or given instead of a portion of the hay, will afford considerable relief. Ten or twelve pounds may be allowed daily, and half that weight of hay substracted.

Rye Grass affords a valuable article of food, but is inferior to the tare. It is not so nutritive. It is apt to scour, and, occasionally, and late in the spring, it is injurious to the horse.

Clover is inferior to the tare and the rye grass, but nevertheless, is useful when they cannot be obtained. Clover hay is, perhaps, preferable to meadow hay for chaff.

\section{THE TIMES OF FEEDING.}

The times of feeding should be as equally divided as convenience will permit; and when it is likely that the horse will be kept longer than usual from home, the nose-bag should invariably be taken. The small stomach of the horse is emptied in a few hours; and if he is suffered to remain hungry much beyond his accustomed time, he will afterwards devour his food so voraciously as to distend the stomach and endanger an attack of staggers.

\section{KIND OF WATER.}

Hard water, drawn fresh from the well, will assuredly make the coat of a horse unaccustomed to it, stare, and it will not unfrequently gripe and otherwise injure him. He is injured, however, not so much by the hardness of the well water as by its coldness-particularly by its coldness in summer, and when it is many degrees below the temperature of the atmosphere. The water in the brook and the pond, being warmed by long exposure to the air, as well as having become soft, the horse drint.s freely of it without danger. 
If the horse has easy and frequent access to water, at any season, he will not drink so much in the course of the day, as another will do, who, to cool his parched mouth, swallows as fast as he can, and knows not when to stop.

On a journey, a horse should be liberally supplied with water. When he is a little cooled, two or three quarts may be given to him, and after that his feed. Before he has finished his corn, two or three quarts more may be offered. He will take no harm if this is repeated three or four times during a long and hot day.

\section{THE SENSE OF SMELL.}

As far as you gratify the horse's sense of smell, by the application of pleasing aromatics, so far you gain the confidence and favor of the horse, just as you would do by giving him a good dinner.

The continual use of the nose in the horse is not to be overlooked or neglected. Since it is his mode of detecting the harmlessness or hurtfulness of any object, you must always submit every thing to this test. If you know it is a mere whim in your herse, and a very unsuccessful way of detecting a steel trap from a coffee mill, still it is his way, and you should always satisfy him by letting him smell of every object he desires to, except a steel trap.

\section{TREATMENT OF 'TIE FEET.}

The feet should be carefully examined every morning, for the shoes may be loose and the horse would be stopped in the middle of his work; or the clenches may be raised, and endanger the wounding of the legs; for the shoe may begin to press upon the sole or the heel, and bruises of the sole, or corn, may be the result.

When the horse comes in at night, and after the harness has been taken off and stowed away, the heets should be well brushed out. Hand-rubbing will be preferable to washing.

The feet of every horse should be stopped, if he remains in the stable. But little clay should be used. Cow-dung is the best stopping. It keeps the feet cool and elastic. Before stopping, the foot should be examined, between shoe and sole, to remove any chance stone, or detect any wound there. 


\section{THE AGE OF A HORSE.}

A curious mode of telling the age of a horse is believed in by some. It is this: After the horse is nine years old, a wrinkle comes on the eyelid at the upper corner of the lower lid, and every year thereafter he has one well defined wrinkle for every year over nine. If, for instance, the horse has three wrinkles, he is twelve; if four, he is thirteen. Add the number of wrinkles to nine, and you will always get it.

\section{TO LEAD A. COLT WITIF A BROKE IHORSE.}

If you should want to lead your colt by the side of another horse, you must first put the horse into a stable with the colt. You now attach a second strap to the colt's halter, and lead your horse up alongside of him. 'Then get on the broke horse and take one strap around his breast under the martingale, (if he has any on,) holding it in your left hand. This will prevent the colt from getting back too far; besides, you have more power to hold him, with the strap pulling against the horse's breast. The other strap take up in your right hand to prevent him from running ahead; then turn him about in the stable, and, if the door is wide enough, ride out with him in that position; if not, take the broke horse out first, and stand his lreast up against the door; then lead the colt to the same spot and take the straps as before directed, one on each side of his neck, and then let some one start the colt out, and as the colt comes out, turn your horse to the left, and you will have them all right. You can manage any kind of a colt in this way, without trouble; for, if he tries to run ahead, or pull back, the two straps will bring the two horses facing each other, so that you can very easily follow up his movements without doing much holding, and as soon as he stops running backward, you are right with him, and all ready to go ahead. If he gets stubborn and does not want to go, you can remove all his stubbornness by riding your horse against his neck, thus compelling him to turn to the right; and as soon as you have turned him about a few times, he will be willing to go along. The next thing, after you are through leading him, will 
be to take him into a stable and hitch him in such a way as not to have him pull on the halter, and as they are often troublesome to get into a stable the first few times, I will give you some in. structions about getting him in.

\section{TO LEAD THE COLT INTO A STABLE.}

You should lead the broken horse into the stable first, and get the colt, if you can, to follow in after him. If he refuses to go, step up to him, taking a little stick or switch in your right hand; then take hold of the halter close to his head with your left hand, at the same time reaching over his back with your right arm so that you can tap him on the opposite side with your switch; bring him up facing the door, tap him slightly with your switch, reaching as far back with it as you can. This tapping, by being pretty well back, and on the opposite side, will drive him ahead, and keep him close to you; then by giving him the right direction with your left hand you can walk into the stable with him. I have walked colts into the stable this way in less than a minute, after men had worked at them half an hour, trying to pull them in. If you cannot walk him in at once in this way, turn him about and walk him around a while until you can get him up to the door without pulling at him. Then let him stand a few minutes, keeping his head in the right direction with the halter, and he will soon walk in of his own accord. Never attempt to pull the colt into the stable; that would make him think at once that it was a dangerous place, and if he was not afraid of it before he would be then. Besides, we do not want him to know anything about pulling on the halter. If you want to tie up your colt, put him in a tolerably wide stall, which should not be too long, and should be connected by a bar, or something of that kind, to the partition behind it; so that, after the colt is in, he cannot go far enough back to take a straight, backward pull on the halter ; then, by tying him in the centre of the stall, it would be impossible for him to pull on the halter, the partition behind preventing him from going back, and the halter in the centre checking him every time he turns to the right or left. In a stall of this kind you can break any horse to stand tied with a light 
strap, anywhere, without his ever knowing anything about pulling. For if you have broken your horse to lead, and have taught him the use of the halter (which you should always do before you hitch him to anything), you can hitch him in any kind of a stall, and if you give him something to eat to keep him up to his place for a few minutes at first, there is not one colt in fifty that will pull on his halter, or ever attempt to do so.

This is an important feature in breaking the colt, for if he is allowed to pull on the halter at all, and particularly if he finds out that he can break the halter, he will never be safe.

\section{KIND OF BIT, AND HOW TO USF IT.}

In first accustoming a colt to the bit, you should use a large, smooth snaffle, so as not to hurt his mouth, with a bar at each side to prevent it from pulling through either way. This should be attached to the head-stall of your bridle, and put it on your colt without any reins to it, and let him run loose in a large stable or shed, some time, until he becomes a little more used to the bit, and will bear it without trying to get it out of his mouth. Repeat this several times, before you do anything more with the colt; and as soon as he will bear the bit, attach a single rein to it, without any martingale. You should also have a halter on your colt, or a bridle made after the fashion of a halter, with a strap to it, so that you can hold or lead him about without pullingmuch on the bit.

Farmers often put bitting harness on a colt the first thing they do to him, buckling it on as tight as they can draw it, to make him carry his head high, and then turn him out in a lot, to run half a day at a time. This is one of the very worst punishments they can inflict on a colt, and is very injurious to a young horse that has been used to running in pasture with his head down. I have seen colts so injured in this way that they never got over it.

A horse should be well accustomed to the bit before you put on the bitting harness, and when you first bit him you should only rein his head up to the point where he naturally holds it, let that point be high or low; he will soon learn that he cannot 
lower his head, and that raising it a little will loosen the bit in his mouth. This will give him an idea of raising his head to loosen the bit; and then you can draw the bitting a little tighter every time you put it on, and he will still raise his head to loosen it. By this means you will gradually get his head and neck in the position you want him to carry it, and give him a nice and graceful carriage without husting him, making him mad, or causing his mouth to get sore. IIorses that have had their heads drawn up tightly, should not have the bitting on more than fiftecn minutes at a time.

\section{HOW TO SADDLE A COL'T.}

Any one who has this theory, can put a saddle on the wildest horse that ever grew, without any help, and without scaring him. The first thing will be to tie each stirrup strap into a loose knot, to make them short and prevent the stirrups from flying about and hitting him. Then double up the skirts and take the saddle under your right arm, so as not to frighten him with it when you approach. When you get to him, rub him gently a few times with your hand, then raise the saddle very slowly, until he can see it, and smell, and feel it with his nose. Then let the skirts loose, and rub it very gently against his neck, the way the hair lays, letting him hear the rattle of the skirts as he feels them against him; each time a little further backward, and finally slip it over on his back. Shake it a little with your hand, and in less than five minutes you can rattle it about over his back as you please, and pull it off and throw it on again, without his paying much attention to it.

As soon as you have accustomed him to the saddle, fasten the girth. Be careful how you do this. It often frightens the colt when he feels the girth hinding him, and making the saddle fit tight on his back. You should bring up the girth very gently, and not draw it too tight at first, just enough to hold the saddle on. Move him a little, and then girth it as tight as you choose, and he will not mind it.

You should see that the pad of your saddle is all right before you put it on, and that there is nothing to make it hurt him, or 
feel unpleasant to his back. It should not have any loose straps on the back part of it, to flap about and scare him. After you have saddled him in this way, take a switch in your right hand to tap him up with, and walk about in the stable a few times with your right arm over you saddle, taking hold of the reins on each side of his neck with your right and left hands, thus marching him about in the stable until you teach him the use of the bridle and can turn him about in any direction, and stop him by a gentle pull of the rein. Always caress him, and loose the reins a little every time you stop him.

You should always be alone, and have your colt in some light stable or shed the first time you ride him; the loft should be high, so that you can sit on his back without endangering your head. You can teach him more in two hours' time in a stable of this kind, than you could in two weeks in the common way of breaking colts, out in an open place. If you follow my course of treatment, you need not run any risk, or have any trouble in riding the worst kind of a horse. You take him a step at a time, until you get up a mutual confidence and trust between yourself and horse. First teach him to lead and stand hitched; next acquaint him with the saddle, and the use of the bit; and then all that remains is to get on him without scaring him, and you can ride him as well as any horse.

\section{HOW TO MOUN'T TIE COLT.}

First gentle him well on both sides, about the saddle, and all over, until he will stand still without holding, and is not afraid to see you anywhere about him. As soon as you have him well gentled, get a small block alout one foot or eighteen inches in height, and set it down by the side of him, about where you want to stand to mount him; step up on this, raising yourself very gently. Horses notice every change of position very closely, and if you were to step up suddenly on the block, it would be very apt to scare him; but by raising yourself gradually on it, he will see you, without being frightened, in a position very near the same as when you are on his back. As soon as he will bear this without alarm, untie the stirrup strap next to you, and put 
your left foot in the stirrup, and stand square over it, holding your knee against the horse, and your toe out, so as to touch him under the fore-shoulder with the toe of your boot. Place your right hand on the front of the saddle, and on the opposite side of you, taking hold of a portion of the mane and reins (they hang lonsely over his neck), with your left hand, then gradually bear your weight on the stirrup, and on your right hand, until the horse feels your whole weight on the stirrup; repeat this several times, each time raising yourself a little higher from the block, until he will allow you to raise your leg over his croup, and place yourself in the saddle. Another, and in some cases a better way of mounting, is to press the palm of your right hand on the off-side of the saddle, and as you rise, lean your weight on it. By this means you can mount with the girths loose, or without any girths at all.

There are three great arlvantages in having a block to mount from. First, a sudden change of position is very apt to frighten a young horse that has never been handled; he will allow you to walk to him, and stand by his side without scaring at you, because you have gentled him to that position; but if you get down on your hands and knees and crawl towards him, he will be very much frightened; and upon the same principle, he would frighten at your new position if you had the power to hold yourself over his back without touching him. Then the first great advantage of the block is to gradually gentle him to that new position in which he wiil see you when you ride him. Secondly, by the process of holding your weight in the stirrups, and on your hand, you can gradually accustom him to your weight, so as not to frighten him by having him feel it all at once. And, in the third place, the block elevates you so that you will not have to make a spring in order to get on the horse's back, but from it you can gradually raise yourself into the saddle. When you take these precautions, there is no horse so wild but what you can mount him without making him jump. I have tried it on the worst horses that could be found, and have never failed in any case. When mounting, your horse should always stand without being held. A horse is never well broke when he has to be held with a tight rein when mounting; and a colt is never so safe to 
mount as when you see that as zurance of confidence, and absence of fear, which cause him to stand without holding.

\section{HOW TO RIDE TIE COLT.}

When you want him to start, do not touch him on the side with your heel, or do anything to frighten him and make him jump. But speak to him kindly, and if he does not start, pull him a little to the left until he starts; then let him walk off slowly with the reins loose. Walk him around in the stable a few times until he gets used to the bit, and you can turn him about in every direction and stop him as you please. It will be well to get on and off a good many times, until he gets perfectly used to it before you take him out of the stable. After you have trained him in this way, which should not take more than two or three hours, you can ride him anywhere you choose without ever having him jump or make an effort to throw you.

When you first take him out of the stable, be very gentle with him, as he will feel a little more at liberty to jump or run, and be easier frightened than he was while in the stable; but you will nevertheless find him pretty well broke, and will be able to manage him without trouble or danger.

When you first mount a colt, take a little the shortest hold on the left rein, so that if anything frightens him, you can prevent him from jumping by pulling his head around to you. This operation of pulling a horse's head around against his side, will prevent him firom jumping ahead, rearing up, or running away. If he is stubborn and will not go, you can make him move by pulling his head around to one side, when whipping him would have no effect. And turning him around a few times will make him dizzy, and then by letting him have his head straight, and giving him a little touch with the whip, he will go along without any trouble.

Never use martingales on a colt when you first ride him; every movement of the hand should go right to the bit in the direction in which it is applied to the reins, without a martin. gale to change the direction of the force applied. You can guide the colt much better without it, and teach him the use of 
the bit in much less time. Besides, martingales would prevent you from pulling his head round if he should try to jump.

After your colt has been ridden until he is gentle and well accustomed to the bit, you may find it an advantage, if he carries his head too high or his nose too far out, to put martingales on him.

You should be careful not to ride your colt so far at first as to heat, worry, or tire him. Get off as soon as you see he is a little fatigued; gentle him and let him rest; this will make him kind to you, and prevent him from getting stubborn or mad.

TO BREAK A HORSE TO HARNESS.

Take him in a tight stable, as you did to ride him; take the harness and go through the same process that you did with the saddle, until you get him familiar with them, so you can put them on his back and rattle them about without his caring for them. As soon as he will bear them, put on the lines, caress him as you draw them over him, and drive him about in the stable till he will hear them over his hips. 'The lines are a great aggravaticn to some colts, and often frighten them as much as if you were to raise a whip over them. As soon as he is familiar with the harness and lines, take him out and put him by the side of a gentle horse, and go through the same process that you did with the balking horse. Always use a bridle without blinds when you are breaking a horse to harness.

\section{TO IITCH A IIORSE IN A SULKY.}

Lead him to and around it; let him look at it, touch it with his nose, and stand by it until he does not care for it; then pull the shafts a little to the left, and stand your horse in front of the off wheel. Let some one stand on the right side of the horse and hold him by the bit, while you stand on the left side, facing the sulky. This will keep him straight. Run your left hand back and let it rest on his hip, and lay hold of the shafts with your right, bringing them up very gently to the left hand, which still remains stationary. Do not let anything but your arm touch 
his back, and as soon as you have the shafts square over him, let the person on the opposite side take hold of one of them, and lower them very gently to the shaft bearers. Be very slow and deliberate about hitching; the longer time you take, the better, as a general thing. When you have the shafts placed, shake them slightly, so that he will feel them against each side. As soon as he will bear them without scaring, fasten your braces, etc., and start him along very slowly. Let one man lead the horse to keep him gentle, while the other gradually works back with the lines till he can get behind and drive him. After you have driven him in this way a short distance, you can get into the sulky, and all will go right. It is very important to have your horse go gently when you first hitch him. After you have walked him awhile, there is not half so much danger of his scaring. Men do very wrong to jump up behind a horse to drive him as soon as they have him hitched. There are too many things for him to comprehend all at once. The shafts, the lincs, the harness, and the rattling of the sulky, all tend to scare him, and he must be made familiar with them by degrees. If your horse is very wild, I would advise you to put up one foot the first time you drive him.

\section{CHOKING, A MEANS OF SUBDUING TIIE HORSE.}

This is another method of conquering a skittish, stubborn or refractory horse. It is resorted to in cases where the measures before described fail to produce the desired effect. The principles on which the plan of choking are based, are, that you must make a powerful appeal to the intelligence of the animal by physical means before you can subdue him. Now we know that most animals, in fighting, seize each other by the throat, and that a dog thus held by his antagonist for a few minutes, on being released, is often so thoroughly cowed that no human artifice can induce him to again resume the unequal contest. It is, then, reasonable to suppose that choking will have a similar effect on the horse. When it can be done without injuring the animal, it is an easy mode of subduing him, for by its operations he becomes docile, and will thereafter receive any instruction which he can 
be made to understand. Teaching the horse, by this means, to lie down at our bidding, tends to keep him permanently gentle towards man, for it is a perpetual reminder of his subdued con. dition.

It requires a good deal of practice to tame a horse success. fully by choking; also a nice judgment to know when he is choked sufficiently, as there is a bare possibility that he might get more than would be good for him. We advise persons not perfectly familiar with a horse to resort rather to the strapping and throwing-down process, unless the animal to be operated upon is so vicious and intractible that he cannot be cured by it. It is the fault of most people who have owned a horse to imagine that they are experts in his management; while, on the contrary, many professional horsemen are the very worst parties to attempt his subjugation.

In practicing the choking process, retire with the animal to be operated upon into a close stable, with plenty of litter upon the floor (tanlark or sawdust is preferable). In the first place fasten up the left fore-leg with a strap, in such a manner that it will be permanently secured. Then take a broad strap with a buckle, or buckle-frame, at the end, and pass it around the neck just back of the jaw-bone. Draw the strap as tight as possible, so tight as to almost arrest the horse's breathing. The strap must not be buckled, but held in this position to prevent slipping back. The animal will struggle for a few minutes, when he will become perfectly quiet, overpowered by a sense of suffucation; the veins in his head will swell; his eyes lose their fire; his knees totter and become weak; a slight vertigo will ensue, and he will grow gradually exhausted. By now backing him around the stable, he will come down on his knees, in which position it is an easy matter to push him on his side, when his throat should be released. You must now operate with the horse in the same manner as described after getting him down by straps. Speak kindly to him, rub him gently the way the hair lies, fondle him in various ways, and he will be completely subdued. You should not atempt to fondle him, however, until you are satisfied that he has got over the excitement which the choking caused 
in him. It is only necessary in extreme cases to repeat the operation of choking, as no horse can effectually resist its terrible effects.

It should be constantly borne in mind that the operator must not be boisterous or violent, and that the greatest possible degree of kindness is absolutely essential. When the horse is prostrate he should be soothed until his eyes show that he has become perfectly tranquil.

There is another process of choking. After tying up your horse to the manger, make friends with him by some one of the coaxing processes heretofore given, and when you get him in thorough good humor with you, begin the choking by seizing him on the throat near the jaw, at the same time holding on to his mane with your left hand. When you have exhausted him sufficiently, let go the mane and rap him gently on the fore-legs until he lies down; or you may touch him with your foot instead. After he is down, rub him gently, speak kindly to him, and, as soon as he is properly composed, fondle and caress him.

\section{GENERAL RULES, AND REMARKS.}

In taming the horse, either by choking or any of the other processes here given, the following rules should be observed: First-When forcing down the horse in either of the ways described, be careful of his neck. Do not let him fall upon that, or he may break it, as the spine of the horse is easily broken. Second-Do not force him down violently under any circum. stances. The way to get him down is by patiently choking him and waiting until he goes down easily and from sheer exhaustion. Thirdly - Keep him very quiet by stroking or patting him with your hand in a gentle and delicate manner, until he is entirely over the excitement which your operations have caused in him. You can generally tell when he is appeased by the expression of his eyes. Fourthly - In backing the horse, never use violence. Hold the halter and off rein in your left hand, while managing him to bring him down.

In teaching a horse to follow you, and in curing him of kicking or biting, or balking, or indeed any bad habit, the choking 
operation is resorted to with equal success as in the case of taming or breaking. If he continues stubborn, you have only to repeat the operation, giving him one or two lessons a day, and in a short time he will be perfectly subdued. A young horse learns to obey quicker than an older one. When you get a horse down by any of the processes we have mentioned, a quarter of an hour or twenty minutes is ample time to keep him prostrate for the purpose of suljugation. Breathing into a horse's nostrils when he is down is practiced by some horse-tamers, and this is undoubtedly a soothing operation, as it brings you into close contact with the animal, thus giving him an opportunity of examining you with his nose-a process peculiar to horses. You should always litter your stable well when you perform these operations of flooring the horse. Clean straw or tanbark, or anything to make a soft stable bottom, will answer.

TO MAKE A IIORSE FOLLOW YOU.

Turn him out into a large stable or shed, where there is no chance to get out, with a halter or bridle on. Go to him and gentle him a little; take hold of the halter and turn him towards you, at the same time touching him lightly over the hips with a long whip. Lead him the length of the stable, rubbing him on the neck, saying, in a steady tone of voice, as you lead him, "Come along, my boy!" or use his name instead of my boy, if you choose. Every time you turn, touch him slightly with the whip, to make him step close up to you, and then caress him with your hand. He will soon learn to hurry up to escape the whip, and be caressed, and you can make him follow you around without taking hold of the halter. If he should stop and turn from you, give him a few sharp cuts about the hind legs, and he will soon turn his head towards you, when you must always caress him. A few lessons of this kind will make him run after you, when he sees the motion of the whip-in twenty or thirty minutes he will follow you around the stable. After you have given him two or three lessons in the stable, take him in a small lot and train him; and from thence you can take him into the road, and make him follow you anywhere, and run after you. 


\section{TO MAKE A HORSE STAND WITHOUT HOLDING.}

After you have well broken him to follow you, stand him in the centre of the stable-begin at the head to caress him, and gradually work backwards. If he moves, give him a cut with the whip, and put him back to the same spot from where he started. If he stands, caress him as before, and continue gentling him in this way until you can get around him without making him move. Keep walking around him, increasing your pace, and only touch him occasionally. Enlarge your circle as you walk around, and if he then moves, give him another cut with the whip, and put him back to his place. If he stands, go to him frequently and caress him, and then walk round him again. Do not keep him in one position too long at a time, but make him come to you occasionally, and follow you around the stable. "Then stand him in another place, and proceed as before. You should not train him more than half an hour at a time.

\section{TO PREVENT A HORSE FROM BEING SCARED.}

This process is very simple. Whenever a horse scares at objects on going along the road, always stop him, and let him face the olject. Lead him slowly towards it, and let him touch it with his nose. 'Take the pains to do this on every occasion, and it will soon break him entirely. If your horse is frightened at an umbrella, you can soon learn him to be used to that. Go into the stable with him, and first let him look at the umbrella hefore it is opened-let him touch it with his nose. Open it a little way, and then let him see it, and finally open it wide. By ordinary patience you can soon learn the horse to have the um. brella opened suddenly in his face, without his being afraid of it. By a similar treatment you can break any horse from scaring at almost anything that may look frightful to him. If you wish to make a trial of this theory, just take a horse into the stable, and let him examine the frightful object a few minutes, after his mode of examining things, and you will be perfectly satisfied. There is a singular fact connected with taming the horse that I would have never believed if I had not tried it. If you accustom him to any particular object by showing it to him on one side, only, he 
will not be afraid when he sees it with the eye on that side, but he will be afraid if you approach him with it on the other side. It is therefore necessary to pacify him on both sides in all cases. After you have accustomed him to the umbrella, or whatever you may wish to make him familiar with, on his right side, repeat the operation on the left side in the same manner as if you had not approached him at all.

\section{RULES TO BE OBSERVED IN FEEDING.}

Never give a horse whole grain. By bruising it, and wetting it with soft water, you save thirty per cent. of its nutritious effects. Steam it in preference to wetting, if you have facilities for doing so. Feed your horse two hours before he begins his day's work. Give him the largest feed at night. Never tie him up to a rack; it is cruel to thus prevent a horse from lying down when he is tired. The best way is to take away your rack alto. gether, and arrange your stable so as to make it unnecessary to tie up the horse. The stable should always be dry and well littered. Never give your horse hard water to drink, if soft water is to be had. If you cannot get soft water, draw the hard water out of the well two hours before you let him drink it. Beans should be full a year old before they are fit to feed to horses; they should be bruised, the same as grain, not ground. Youatt recommends for horse feed, the following misture: Cut hay, two parts; cut straw, three parts-add to this a quantity of bruised beans, oats, or other grain-wet the whole with soft water, and mix it well. Do not feed your horse too much hay, as it is not only a waste of provender, but when he is put to work with an overloaded stomach it endangers his wind. If left to pull hay out of the rack at pleasure, a horse will eat and waste some thirty pounds a day, whereas, by cutting up his hay and mixing it with other feed, as above described, ten pounds is an ample abundance for twenty-four hours. Horses, when worked, should be fed three or four times a day with a mixture of hay, straw and grain, as above described. Give them their food in the manger, and be careful that it is sweet and clean. By following these rules, your horses will always be in good condition- 
will not have that swelled belly so peculiar to animals who are allowed to fill their stomachs with hay-and will usually enjoy good health.

\section{RULES FOR PURCHASING A IrORSE.}

When yon are looking to purchase a horse, first examine the eyes well. The best judges are sometimes deceived in the eyes, therefore you cannot be too careful. Clearness of the Eyes is a sure indication of their goodness; but this is not all that should be attended to: the eyelids, eyebrows, and all the other parts, must also be considered; for many horses, whose eyes appear clear and brilliant, go blind at seven or eight years old. Therefore be careful to observe whether the parts between the eyclids and the eyebrows are free from bunches, and whether the parts round the under eyelids be full, or swelled; for these are indications that the eyes will not last. When the eyes are remarkably flat, or sunk within their orbits, it is a bad sign; also when they look dead and lifeless. The iris, or circle that surrounds the sight of the eye, should be distinct, and of a pale, variegated, cinnamon color, for this is always a sure sign of a good eye, and it adds beauty to the appearance of the animal.

In the next place, examine the Teeth, as you would not wish to purchase an old horse, nor a very young one for' service.

The Feet should next be regarded; for a horse with bad feet is like a house with a weak foundation, and will do little service. The fect should be smooth and tough, of a middle size, without wrinkles, and neither too hard and brittle, nor too soft; the Heels should be firm, and not spongy and rotten; the Frogs horny and dry; the Soles somewhat hollow, like the inside of a dish or bowl. Such fect will never disappoint your expectations, and such only should be chosen.

Particular regard should be had to the Shoulders; they should not be too much loaded, for a horse with heavy shoulders can never move well; and on the other hand, one that has very thin shoulders, and a narrow chest, though he may move briskly so long as he is sound, yet he is generally weak, and easily lamed in the shoulders; a medium should therefore be chosen. 
The Body, or Carcass, should neither be too small nor too large. The Back should be straight, or have only a moderate sinking below the Withers; for when the back of a horse is low, or higher behind than before, it is both very ugly and a sign of weakness. The back should also be a proper length. The Ribs should be large, the Flanks smuoth and full, and the Hindparts, or uppermost Haunches, not higher than the shoulders. When the horse trots before you, observe if his haunches cover his fore-knees. A horse with a short hind-quarter does not look well.

The next thing to be regarded in a horse is his Wind, which may be easily judged of by the motion of his flanks. A broken. winded horse also pinches in his flanks, with a very slow motion, and drops them suddenly, which may be easily perceived. Many horses breathe thick that are not broken-winded; indeed, any horse will in foggy weather, or if foul fed, without sufficient exercise; but if a horse has been in good keeping, and had proper exercise, and yet has these symptoms, there is some defect, either natural or accidental; such as a narrow chest, or some cold that has effected the lungs.

There are other particulars that should be observed in choos. ing a horse. If his Head be large and fleshy, and his Neck thick and gross, he will always go heary on the hand, and therefore such should never be chosen. A horse that has his Hocks very wide, seldom moves well, and one that has them too near will chafe and cut his legs hy crossing them. Fleshy-legged horses are generaly subject to the Grease, and other infirmities of that kind, and therefore should not be chosen.

The Temper of a horse should be particularly attended to. Avoid a fearful horse, which you may know at first sight by his starting, crouching, or creeping, if you approach him. A hot and fretful horse is also to be avoided, but the buyer should be careful to distinguish between a hot, fretful horse, and one that is eager and craving. The former begins to fret the moment he is out of the stable, and continues in that humor till he has quite fatigued himself; and the latter only endeavors to be foremost in the field, and is truly valuable; he has those qualities that resem- 
ble prudence and courage; the other those of intemperate heat and rashness.

A horse that goes with his fore feet low is very apt to stumble ; and there are some that go so near the ground that they stumble most on even roads; and the dealers, to remedy this, put heavy shoes on their feet, for the heavier a horse's shoes are, the higher he will lift his feet. Care also should be taken that the horse does not cut one leg with the other. A horse that goes near the ground will cut the low side of the fetlock joint, but one that goes high cuts below the knee, which is called the speedy cut. A horse that lifts his feet high, generally trots fast, but is not the easiest for the rider. Some horses cut with the spurn of the foot, and some with the heel; but this you may soon perceive by their standing; for if a horse points the front of his foot inward, he cuts with the spurn, and if outward, with the heel.

These few instructions may be of use in purchasing horses; but I advise every one to get some experimental knowledge of them before he trusts to his own jurlgment, for the dealers have so many arts to hide the defects of their horses, that the best judges are often deceived.

\section{DISEASES AND THEIR CURE.}

TO MIX A BALL.

A ball should never weigh over an ounce and a half; it should be an inch in diameter, and two to three inches long; mix the medicine whatever it may be, with oil and meal flour, or any similar substance. Mix only for a few days at a time, lest they become hard and injure the horse.

\section{TO GIVE A BALL.}

Never use an iron or wooden instrument to push it down. Back the horse in the stall, talk to him in a kindly tone all the 
while, have the ball in the right hand, with the left gently draw out the tongue and hold it on the off side of the mouth, pressing the fingers against the side of the lower jaw. Now with the right hand pass the ball down the throat, not losing your hold of it, nor letting it touch the tongue or sides of the mouth, until it reaches the palate, then give it a toss, instantly withdrawing the hand, and give the horse a slight tap under the chin, and down it will go.

\section{GLANDERS.}

The earliest symptoms of Glanders is an incercased discharge from the nostril, small in quantity, constantly flowing, of a watery charcter, and a little mucus mingling with it.

If a horse is in the highest condition, yet has this small watery constant discharge, and especially from one nostril, no time should be lost in separating him from his companions.

Glanders have often been confounded with strangles, and by those who ought to have known better. Strangles are peculiar to young horses. They have also been confounded with catarrh or cold; but the distinction between them is plain enough. Fever, and loss of appetite and sore throat, accompany cold. In glanders, there is seldom cough of any consequence, and generally no cough at all.

In a well settled case of glanders it is not worth while, except by way of experiment at a veterinary school, to attempt any remedies. The chances of cure are too remote, and the danger of infection too great.

If, however, remedial measures are resorted to, a pure atmosphere is that which should first be tried. 'Turn out the horse, and, if practicable, on a salt marsh-but much caution is requisite, as the grass, and even the fences may receive the glanderous matter; and, hardening on them, it may months afterward, communicate the disease to horses; and there is not yet decided proof that sheep and cattle are not sulject to the same malady.

\section{DISEASES OF THE TEETH.}

Of the diseases of the teeth in the horse, we know little. Carious or hollow teeth are occasionally, but not often, seen; but 
the edges of the grinders, from the wearing off of the enamel, or the irregular growth of the teeth, become rough, and wound the inside of the cheek; it is then necessary to adopt a summary, but effectual mode of cure ; namely, to rasp them smooth. Many bad ulcers have been produced in the mouth by neglect of this.

The teeth sornetimes grow irregularly in length. They should be reduced to the level of the others with a saw, and occasionally looked to, because the difficulty will return. Decayed teeth should be removed to prevent injury to the other teeth and to the jaw.

Fever, cough, catarrhal affections generally, disease of the eyes, cutaneous affections, diarrhœa, loss of appetite, and general derangement, will frequently be traced by the careful observer to irritation from teething, in the colt.

It is a rule scarcely admitting of the slightest deviation, that, when young horses are laboring under any febrile affection, the mouth should be examined, and if the tushes are prominent and pushing against the gums, a cut in the form of a cross should be made upon them. Relief will often be immediate.

\section{INFLAMMATION OF THE EXE.}

The Common Inflammation is generally sudden in its attack. The lids will be found swelled and the eyes partialy closed, and some weeping. The inside of the lit will be red, some red streaks visible on the white of the eye, and the corner slightly dim. Cooling applications to the eye, as the Goulard's extract or tincture of opium, with mash-diet, and gentle physic, will usually abate the evil; or the inflammation will subside without medical treatment.

\section{POLL-EVIL.}

From the horse rubbing and sometimes striking his poll against the lower end of the manger, or hanging back in the stall and bruising the part with the halter-or from the frequent and painful stretching of the ligaments and muscles by unnecessary tight reining, and, occasionally, from a violent blow on the 
poll, inflammation ensues, and a swelling appears, hot, tender, and painful.

The first thing to be attem $\mathrm{i}^{\mathrm{t} t} \cdot \mathrm{d}$ is to abate the inflammation by bleeding, physic, and the application of cold lotions to the part. In a very early period of the case, a blister might have consid. erable effect. Strong purgatives should also be employed. By these means the tumor will sometimes be dispersed. This sys. tem, howerer, must not be pursued too far. If the swelling increases, and the heat and tenderness likewise increase, matter will form in the tumor; and then our olject should be to hasten its formation by warm fomentations, poultices, or stimulating embrocations. As soon as the matter is formed, which may be known by the softness of the tumor, and before it has time to spread around and eat into the neighboring parts, it should be eracuated. Now comes the whole art of treating poll-eril; the opening ints the tumor must be so contrived that all the matter shall run out, and continue afterwards to run out as quickly as it is formed, and not collect at the bottom of the ulcer, irritating and corroding it. This can be effected by a setun alone. The needle should enter at the top of the tumor, penetrate through its bottom, and be brought out at the side of the neck, a little below the abscess. Without anything more than this, except frequent fomentation with warm water, in order to keep the part clean. and to obviate inflammation, poll-evil in its early stage will fre. quently be cured.

\section{STRAXTGLES.}

This is a disease principally incident to roung horses. It is preceded by a cough, and can at first be scarcely distinguished from common cough, except that there is more discharge from the nostril, of a yellowish color, mired with pus, and generaily without smell.

As soon as the tumor under the jaw is decidedly apparent, the part should be actively blistered. From the thickness of skin. poultices, fomentations, etc.. are of little arail. The blister will also abate the internal inflammation and soreness of the throat, and thus lessen the cough and wheezing.

As soon as the swelling is soft on its summit, and evidently 
contains matter, it should be freely and deeply lanced. The remainder of the treatment will depend on the symptoms. If there is much ferer, and evident affection of the chest, and which should carefuly be distinguished from the oppression and choling occasioned by the pressure of the tumor, it will be proper to bleed. In the najority of cases, howerer, bleeding wil! not only be unnecessary, but injurious. A few couling medicines, as niter, emetic tartar, and perhaps digitalis, may be giren, as the case requires.

\section{PALSF.}

It commences generally in one hind.leg. or perhaps both are equally affected. The animal can scarcely waik-he walks on his fetlocks instead of his soles-he staggers at every motion. At length he falls. He is raised with difficulty, or he never rises again.

The treatment is simple. It should commence with bleeding until the pulse begrins to falter or the horse to reel. To this should fullow a strung cathartic. The loins should be corered with a mustard prultice frequently renewed. The borse should be warmly clothed, supplied plentifully with mashes, but without a hernel of grain in them; and frequent injections administered.

\section{Y.ATGE}

Is a pimpled or resicular eruption. After awhile the resicles break, or the cuticle and the hair fall ofî, and there is. as in obstinate surietit, a bare spat corered wih scurf-some fluid oozing from the skin beneath. and this changing to a scab, which likewise soon peels offi, and leaves a wider spot. This process is attended with consideralle itching and tenderness. and thickening of the skin, which soon becomes more or less folded, or puckered. The mange generaily first appears on the neck at the root of the mane, and its existence may be suspected even befure the blotches appear, and when there is onls consid rable itchiness of the part, by the ease with which the short hair at the root of the mane is plucked out. From the neck it spreads upward to the head, or downward to the withers and back, and occasionally extends over the whole carcass of the horse. 
One cause of it is neglected or inveterate surfeit. Several instances are on record in which poverty of condition, and general neglect of cleanliness, preceded or produced the most violent mange. The most common catuse is contagion. Amidst the whole list of diseases to which the horse is exposed, there is not one more highly contagious than mange. If it once gets into a stable, it spreads through it, for the slightest contact seems suffcient for the communication of this noisome complaint.

If the same brush and currycomb is used on all the horses, the propagation of mange is assured; and horses feeding in the same pasture with a mangy one rarely escape, from the propensity they have to nibble one another.

'The propriety of bleeding in cases of mange depends on the condition of the patient. If mange is the result of poverty, and the animal is much debilitated, bleeding will increase the evil, and will probably deprive the constitution of the power of rallying. Physic, however, is indispensable in every case. But mange in the horse resembles itch in the human being-medi. cine alone will never effect a cure. There must be some local application. Sulphur is indispensable for mange. In an early and not very acute state of Inange, equal portions of sulphur, turpentine, and train-oil, gently but well rubbed on the part, will be applied with advantage. A tolerably stout brush, or even a currycomb, lightly applied, should be used, in order to remove the dandruff or scurf. After that, the horse should be washed with strong soap and water as far as the disease has extended; and, when he has been thoroughly dried, the ointment should be well rubbed in with the naked hand, or with a piece of flannel.

During the application of the ointment, and as soon as the physic has set, an alterative ball or powder should be daily given. If, after some days have passed, no progress should appear to have been made, half a pound of sulphur should be well mixed with a pint of oil of tar, or, if that is not to be obtained, a pint of Barbadoes tar, and the affected parts rubbed, as before. On every fifth or sixth day, the ointment should be washed off with warm soap and water. The pregress towards cure will thus be 
ascertained, and the skin will be cleansed, and its pores opened for the more effectual application of the ointment.

It will be prudent to give two or three dressings after the horse has been apparently cured, and to continue the alteratives for ten days or a fortnight.

\section{SURFEIT.}

Large pimples or eruptions often appear suddenly on the skin of the horse, and especially in the spring of the year. The disease most frequently appears when the skin is irritable during or after the process of moulting, or when it sympathizes with any disorder of the stomach. It has been known to follow the eating of poisonous herbs or mowburnt hay, but, much oftener, it is to be traced to exposure to cold when the skin was previously irritable and the horse heated by exercise.

If there is simple eruption, without any marked inflainmatory action, alteratives should be resorted to. There is no better alterative than that which is in common use, pulverized antimony, niter, and sulphur. They should be given on several successive nights. The night is better than the morning, because the warmth of the stable will cause the antimony and sulphur to act more powerfully on the skin. The horse should be warmly clothed-half an hour's walking exercise should be given, an additional rug thrown over him-such green feed as can be procured should be used in moderate quantities, and the chill should be taken from the water.

Should the eruption continue or assume a more violent charac. ter, bleeding and aloes must be had recourse to, but neither should be carried to any extreme. The physic having set, the alteratives should again be had recourse to, and attention should be paid to the comfort and diet of the horse.

\section{TETANUS OR LOCKED JAW.}

The horse, for a day or two, does not appear to be quite well; he does not feed as usual; he partly chews his food, and drops it; and he gulps his water.

The ears are erect, pointed forward, and immovable; if tho 
horse is spoken to, or threatened to be struck, they change not their position.

The treatment of tetanus is simple-the system must be tranquilized. The grand agent in accomplishing this is copious bleeding. The animal should be bled until he falls, or the pulse evidently falters. Twenty pounds of blood have been safely taken in such case.

The profuse bleeding will generally relax the muscles of the jaw, so that a dose of physic can be administered. Eight or ten drachms of aloes should be given. If the remission of the spasm is slight, there is another purgative-not so certain in its action, but more powerful when it does act-the farina of the Croton nut.

Clysters will be useful in assisting the action of the purgative. A solution of Epsom salts will constitute the safest and best injection. As to medicine, opium is not only a valuable drug, but it is that on which alone dependence can be placed in this disease. It will be borne in doses, from half a drachm to two drachms.

Gentle friction with the hand along the course of the spine, and the application of an opiate liniment, is highly useful.

\section{WARTS.}

There are some caustics available, but frequently they must be removed by an operation. If the root is very small, it may be snipped asunder, close to the skin, with a pair of scissors, and touched with the lunar càstic. If the pedicle or stem is somewhat larger, a ligature of waxed silk should be passed firmly round it, and tightened every day.

\section{BOTS}

Are caused by the egg of the Gad-fly, being licked from the skin of the horse, and thus conveyed to the stomach, where they are hatched, cling to the stomach, and are finally evacuated.

Some writers, as Youatt and others, contend that they are incurable, while others recommend fresh blood, sweetened milk, or anything that will nauseate slightly. A writer in the Eastern Agriculturalist recommends giving a few sheaves of barley. 
It is seldom I pay any attention to them, but when I do, it is in the use of some simple remedy, like sweetened milk, sometimes followed by half a pint of ground mustard seed.

\section{RABIES, OR MADNESS.}

This is a fearful disease of the nervous system. It results from the bite of a rabid animal, and, most commonly, of the companion and friend of the horse-the coach-dog.

The horse goes out to his usual work, and, for a certain time and distance, performs it as well as he has been accustomed to do; then he stops all at once-trembles, heaves, paws, staggers and falls.

When the disease can be clearly connected with a previous bite, the sooner the animal is destroyed the better, for there is no cure. If the symptoms bear considerable resemblance to rabies, although no bite is suspected, the horse should at least be slung, and the medicine, if any is administered, given in the form of a drink, and with the hand well protected; for if it should be scratched in balling the horse, or the skin should have been previously broken, the saliva of the animal is capable of communicating the disease.

If a horse is bitten by a dog under suspicious circumstances, he should be carefully examined, and every wound, and even the slightest scratch, well burned with the lunar caustic (nitrate of silver). The scab should be removed and the operation repeated on the third day. The hot iron does not answer so well, and other caustics are not so manageable. The caustic must reach every part of the wound.

\section{FITS OR EPILEPSY.}

The only hope of cure consists in discovering the cause of the fits; and an experienced practitioner must be consulted, if the animal is valuable. Generally speaking, however, the cause is so difficult to discover, and the habit of having fits is so soon formed, and these fits will so frequently return, even at a great distance of time, that he who values his own safety, or the lives of his family, will cease to use an epileptic horse. 


\section{GALLS ON HORSES, ETC.}

One of the best means to prevent galls on horses, is to wash the parts most liable to injury with whisky, saturated with alum. The following is an excellent receipt for an ointment for wounds and sores of all kinds, and for horses, when galled by the saddle or collar, and also for broken chilblains : Take of honey twelve ounces, yellow beeswax four ounces, compound galbanum plaster six ounces, sweet oil half a pint. Put the honey into a jar by the fire, then melt the other ingredients and mix them together, to be spread very thin on linen, and changed twice a day.

\section{HEAVES.}

This disease is so well known that nothing need be said of its symptoms, causes or effects. Twenty remedies at least are known to the Veterinary Physician, and probably every farmer knows of five. About the best I know of is a mixture of equal parts of Balsam Copavia and Balsam of Fir, with enough of magnesia to enable you to make into balls about the size of a crab apple, and give one every night and morning, until a cure is effected.

\section{TO CURE WORMS.}

Worms are indicated by a dull, sleepy appearance of the eyes; by the rough appearance of the hair and want of gloss, and by the horse losing flesh without any other apparent cause. He also shows less inclination to eat, and if too long neglected, worms will often pass through the bowels and be discharged in the dung.

A pint of neat's foot oil followed in about 24 hours with half pint of castor oil is the best remedy known.

Two drachms of Tartar Emetic, mixed with a little ground glass or filings of tin, compose an excellent remedy.

\section{colic.}

The appearance of this disease may be known from the coldness of the horse's ears and legs, and by his general uneasiness, getting up and laying down often, looking around at his flanks, etc.

Take the proportions of $1 \mathrm{oz}$. black pepper to half pint of whiskey, mix, shake and rub on the belly of the horse. 


\section{LIBRARY OF CONGRESS}

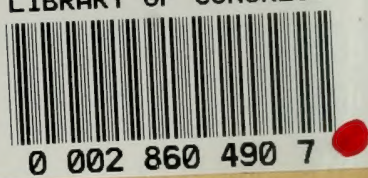

